Bull. Chem. Soc. Ethiop. 2012, 26(1), 43-54.

Printed in Ethiopia

ISSN 1011-3924

DOI: http://dx.doi.org/10.4314/bcse.v26i1.5

\title{
COMPOSITION, MINERAL SAFETY INDEX, CALCIUM, ZINC AND PHYTATE INTERRELATIONSHIPS IN FOUR FAST-FOODS CONSUMED IN NIGERIA
}

\author{
E.I. Adeyeye $^{1 *}$, O.T. Orisakeye ${ }^{1}$ and M.A. Oyarekua ${ }^{2}$ \\ ${ }^{1}$ Department of Chemistry, University of Ado-Ekiti, PMB 5363, Ado-Ekiti, Nigeria \\ ${ }^{2}$ Department of Biological and Chemical Sciences, University of Science and Technology, PMB \\ 306, Ifaki Ekiti, Nigeria
}

(Received November 5, 2010; revised September 14, 2011)

\begin{abstract}
The proximate, mineral and amino acid contents and calculated values of calcium/phytate $\mathrm{Ca} / \mathrm{Phy}, \mathrm{Zn} / \mathrm{Phy},[\mathrm{Ca}][\mathrm{Phy}] /[\mathrm{Zn}], \mathrm{Ca} / \mathrm{P}, \mathrm{Na} / \mathrm{K}, \mathrm{Ca} / \mathrm{Mg},[\mathrm{K} /(\mathrm{Ca}+\mathrm{Mg})]$, mineral safety index (MSI) for $\mathrm{Na}, \mathrm{Mg}, \mathrm{P}$, $\mathrm{Ca}, \mathrm{Fe}$ and $\mathrm{Zn}$, and the amino acid scores were determined in four fast-foods consumed in Nigeria. The fast-foods were meat pie, doughnut, moin-moin (steamed bean pudding) and cake. In the proximate: protein ranged 156-327 $\mathrm{g} / \mathrm{kg}$, carbohydrate ranged 467-664 g/kg and energy ranged 14-16 mega Joules (14-16 MJ/kg). In minerals: $\mathrm{Zn}$ ranged $323-1071 \mathrm{mg} / \mathrm{kg}$ and $119-327 \mathrm{mg} / \mathrm{kg}$ in $\mathrm{Fe}$ while $\mathrm{Cu}$ and $\mathrm{Co}$ were not detected. The highest phytate level $(2554 \mathrm{mg} / \mathrm{kg})$ was observed in moin-moin. [Ca][Phy]/[Zn] ranged 0.04-0.06 showing Zn availability for body biochemical use. The essential amino acids were on the high side with range of $243-317 \mathrm{mg} / \mathrm{g}$ crude protein. The limiting amino acids varied. The best MSI was observed for $\mathrm{Ca}$ while the worst was observed for $\mathrm{Zn}$ showing that $\mathrm{Zn}$ might have some deleterious effects. Two independent experiments were conducted.
\end{abstract}

KEY WORDS: Fast-foods, Minerals, Amino acids, Mineral Safety Index

\section{INTRODUCTION}

Trends in food consumption have been accompanied by changes in eating patterns. Traditional family meals have been replaced, in part, by between-meal snacks and by meals eaten away from the home [1]. These trends are expected to continue for several reasons [2]. These include increasing employment among women, decrease in family size, increase in per capital income, change from traditional life-styles and a general desire and demand for convenience [2].

Good nutrition requires that people learn to eat in a rational way, whether snacking, eating at home, or eating away from home. Eating nutritiously on the road is becoming easier with the increase in variety of healthful foods offered at both fast-food restaurants and supermarkets.

Fast food restaurants now corner state capitals and some major cities in Nigeria. Major concerns about fast-foods include their tendency to be high in sodium, fat and calories while being low in vitamins $\mathrm{A}$ and $\mathrm{C}$ and in dietary fibre [2]. However, not all fast foods may be having these traits. In Nigeria, we have the Association of Fast Food and Confectionary Operators of Nigeria (AFFCON). No report is available on the nutritional qualities of fast-foods in Nigeria. However, available reports are found on the bacteriological examination of some ready-to-eat or fast-foods [3-5].

The purpose of this paper is to document and provide data on the chemical composition (and other related calculated values) in order to characterize fast-foods consumed in Nigeria: highlight the health implications of the foods composition, as is deemed appropriate.

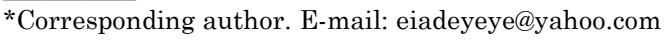




\section{Collection of samples}

\section{EXPERIMENTAL}

Fast-food samples were collected from Mr Big's (a fast-food restaurant) in Ado-Ekiti, Nigeria. This is the most patronized fast-food restaurant in Ado Ekiti, Nigeria. The samples were collected when hot. The samples were meat pie, doughnut, moin-moin (steamed bean pudding) and cake. These samples were the mostly consumed fast-foods in the restaurant. The samples of the products were collected five times leading to five independent experiments.

\section{Sample treatment}

Ingredients. The ingredients for the preparation of meat pie were: meat, Irish potatoes, wheat flour, baking powder, butter, tap water, table salt, pepper, onions, seasonings and sausage meat. For doughnut, ingredients were: wheat flour, baking powder, baking yeast, granulated sugar, hot tap water and butter. Ingredients for the preparation of moin-moin (steamed bean pudding) were: beans, pepper, onions, vegetable oil, cray fish/egg/meat and table salt. For preparation of cake, ingredients were: wheat flour, baking powder, eggs, butter, flavouring agents, table salt, preservatives, granulated sugar and particularly nutmeg.

The samples were first oven dried at a temperature of $100{ }^{\circ} \mathrm{C}$ for $1 \mathrm{~h}$. After drying, the samples were milled into fine powder with a Kenwood major blender, Model Titanium KM020 (Kenwood Chef Major, Giovanni, UK). The samples were sieved with $200 \mathrm{~mm}$ mesh, stored in dry plastic bottles and then kept in a laboratory refrigerator for preservation pending analyses. Known weights of samples were taken, dry ashed at a temperature of $540{ }^{\circ} \mathrm{C}$ in the Carbolite furnace (all types of electric heated chamber 30-1800 ${ }^{\circ} \mathrm{C}$ ) (Carbolite, Derbyshire, UK) to constant weight. The ashed samples were each transferred into a $50 \mathrm{~mL}$ beaker, crucible was washed with $25 \mathrm{~mL}$ of $20 \%$ (v/v) nitric acid into corresponding beaker and the beaker was heated to boiling to break the ash. The solution was carefully filtered and transferred into $50 \mathrm{~mL}$ standard flask and made up to the mark with distilled-deionized water.

About $2.0 \mathrm{~g}$ of homogenized sample each was defatted with chloroform/methanol mixture. Between 30-35 mg of defatted sample was put in glass ampoule, $7 \mathrm{~mL}$ of $6 \mathrm{M} \mathrm{HCl}$ was added and oxygen expelled. The sealed ampoule was put in oven at $105 \pm 5{ }^{\circ} \mathrm{C}$ for $22 \mathrm{~h}$ and later allowed to cool before the content was filtered. The filtrate was evaporated to dryness at $40{ }^{\circ} \mathrm{C}$ under vacuum. Residue was dissolved with $5 \mathrm{~mL}$ acetate buffer $(\mathrm{pH}=2)$.

\section{Proximate analysis}

Moisture, total ash, fibre and ether extract of the samples were determined by the methods of the AOAC [6]. Nitrogen was determined by a micro-Kjeldahl method [7] and the crude protein content was calculated as $\mathrm{N} \times$ 6.25. Carbohydrate was determined by difference. All the proximate results were reported as $\mathrm{g} / \mathrm{kg}$ dry weight. The energy values were calculated by adding up the values obtained for carbohydrates (x $17 \mathrm{~kJ})$, crude protein $(\mathrm{x} 17 \mathrm{~kJ})$ and crude fat (x $37 \mathrm{~kJ})$ for each of the samples. Determinations were in duplicate.

\section{Mineral analysis}

The mineral elements were determined in the solutions obtained as above $-\mathrm{Na}$ and $\mathrm{K}$ by flame photometry, Model 405 (Corning, Halstead Essex, UK) using $\mathrm{NaCl}$ and $\mathrm{KCl}$ to prepare standards. Minerals were analysed using the solutions obtained by dry ashing the samples at 550 ${ }^{\circ} \mathrm{C}$ and dissolving it in $10 \% \mathrm{HCl}(25 \mathrm{~mL})$ and $5 \%$ lanthanum chloride $(2 \mathrm{~mL})$, boiling, filtering and making up to standard volume with deionized water. $\mathrm{P}$ was determined colorimetrically 
using a Spectronic 20 (Gallenkamp, London, UK) instrument, with $\mathrm{KH}_{2} \mathrm{PO}_{4}$ as a standard. All other elements ( $\mathrm{Co}, \mathrm{Fe}, \mathrm{Cu}, \mathrm{Ca}, \mathrm{Mg}, \mathrm{Zn}, \mathrm{Cr}$ and $\mathrm{Mn}$ ) were determined by atomic absorption spectrophotometry, Model 403 (Perkin-Elmer, Norwalk, Connecticut, USA). All determinations were made in duplicate. All chemicals used were of analytical grade, and were obtained from British Drug Houses (BDH, London, UK).

The detection limits for the metals in aqueous solution had been determined just before our mineral analyses using the methods of Varian Techtron [8], giving the following values in $\mu \mathrm{g} / \mathrm{mL}$ : Co (0.01), Fe (0.01), Cu (0.002), Na (0.002), K (0.005), Ca (0.04), Mg (0.002), Zn (0.005), Mn (0.01) and $\mathrm{Cr}(0.02)$. The optimal analytical range was 0.1 to 0.5 absorbance units with coefficients of variation from $0.9-2.2 \%$.

\section{Determination of phytate}

Phytate was quantified using the method described by Harland and Oberleas [9]. The blank was also prepared by Harland and Oberleas [9] method. The colorimeter used was a Spectronic 20 (Gallenkamp, UK). The amount of phytate in the sample was calculated as hexaphosphate equivalent using the formula:

Phytate, $\mathrm{mg} / \mathrm{g}$ sample = mean $\mathrm{K}$ x A x $20 /(0.282 \times 1000)$ where $\mathrm{A}=$ absorbance; mean $\mathrm{K}=$ std $\mathrm{P}(\mu \mathrm{g}) / \mathrm{A} / \mathrm{n}$ (stds); phytate $=28.2 \% \mathrm{P}$.

\section{Determination of amino acid}

The method of amino acid analysis was by ion-exchange chromatography (IEC) [10] using the Technicon Sequential Multisample Amino Acid Analyzer (TSM) Model TSM (Technicon Instruments Corporation, New York, USA). Samples $(2.0 \mathrm{~g})$ of each group were defatted with chloroform/methanol (2:1) mixture. Between 30-35 mg of the defatted sample was put in a glass test tube, $7 \mathrm{~mL}$ of $\mathrm{HCl}$ was added and oxygen expelled by flushing with nitrogen gas. The sealed test tube as put in an oven at $105 \pm 5{ }^{\circ} \mathrm{C}$ for $22 \mathrm{~h}$ and later allowed to cool before the content was filtered. The filtrate was evaporated to dryness at $40{ }^{\circ} \mathrm{C}$ under vacuum. The residue was dissolved with $5 \mathrm{~mL}$ acetate buffer ( $\mathrm{pH}$ 2.0). Determinations were in duplicate. The period of an analysis lasted for $76 \mathrm{~min}$ for each sample. The column flow rate was $0.50 \mathrm{~mL} / \mathrm{min}$ at 60 ${ }^{\circ} \mathrm{C}$ with reproducibility within $\pm 3 \%$.

\section{Estimation of quality of dietary protein}

The quality of dietary protein can be measured in various ways [11] but basically it is the ratio of available amino acids in the food or diet compared with needs expressed as a ratio [12-14].

\section{Statistical analyses}

The Phy:Zn, Ca:Phy and [Ca][Phy]:[Zn] values were calculated according to the method of Wyatt and Triana-Tejas [15]. The coefficients of variation percent were calculated [16]. Ca/P, $\mathrm{Na} / \mathrm{K}, \mathrm{Ca} / \mathrm{Mg}$ and the milliequivalent ratio of $[\mathrm{K} /(\mathrm{Ca}+\mathrm{Mg})][17]$; the mineral safety index (MSI) [17] of $\mathrm{Na}, \mathrm{Mg}, \mathrm{P}, \mathrm{Ca}, \mathrm{Fe}$ and $\mathrm{Zn}$ were also calculated. The differences between the standard MSI and the MSI of the samples were also calculated. The chi-square was compared with $\left(\mathrm{Chi}^{2} \mathrm{~T}\right)$ setting the level of confidence at $\alpha<0.05$ [16]. 


\section{RESULTS AND DISCUSSION}

\section{Proximate composition}

Table 1 shows the proximate composition of the fast-food samples. Protein was generally high with values ranging from $156 \mathrm{~g} / \mathrm{kg}$ (cake) to $327 \mathrm{~g} / \mathrm{kg}$ (meat pie). The constituents of the various fast-foods could have resulted into these results. Carbohydrate was also high with value range of $467 \mathrm{~g} / \mathrm{kg}$ (moin-moin) to $663 \mathrm{~g} / \mathrm{kg}$ (doughnut); moin-moin was made from bean pudding, hence its lowest level of carbohydrate. The values of ether extract, ash and fibre were generally low. While the low ether extract was an advantage, the low level of fibre could be deleterious [18]. The energy values were high with a range of $13733 \mathrm{~kJ} / \mathrm{kg}$ (cake) to $16395 \mathrm{~kJ} / \mathrm{kg}$ (doughnut) showing them to be good sources of concentrated energy; however these values were lower than in cereals [19]. The crude protein values of 156 to $327 \mathrm{~g} / \mathrm{kg}$ was a reflection of the composition of the samples; meat pie had the highest value $(327 \mathrm{~g} / \mathrm{kg})$ because meat was part of the ingredients whilst moin-moin was second $(313 \mathrm{~g} / \mathrm{kg})$ because it's major ingredient were bean seeds which is a major source of protein; however, cake had the least value $(156 \mathrm{~g} / \mathrm{kg})$ because it's major ingredient was wheat flour. Fibre content was highest $(7.2 \mathrm{~g} / \mathrm{kg})$ in the doughnut sample likely because of its high content of wheat flour in the ingredient.

Table 1. Proximate composition $(\mathrm{g} / \mathrm{kg})$ of fast-food samples.

\begin{tabular}{|c|c|c|c|c|c|}
\hline \multirow[t]{2}{*}{ Parameter } & \multicolumn{4}{|c|}{ Fast-food samples } & \multirow[b]{2}{*}{$\mathrm{CV} \%^{\mathrm{b}}$} \\
\hline & Meat pie & Doughnut & Moin-moin & Cake & \\
\hline Moisture & $91.1 \pm 0.07$ & $80.4 \pm 0.07$ & $87.6 \pm 0.14$ & $83.8 \pm 0.07$ & 5.4 \\
\hline Crude protein & $327 \pm 1.41$ & $164 \pm 0.07$ & $313 \pm 1.41$ & $156 \pm 2.12$ & 38.7 \\
\hline Ether extract & $53.4 \pm 0.21$ & $63.1 \pm 0.28$ & $49.1 \pm 0.07$ & $55.0 \pm 2.12$ & 10.6 \\
\hline Ash & $30.6 \pm 0.07$ & $22.4 \pm 0.04$ & $77.4 \pm 0.04$ & $170 \pm 0.07$ & 90.1 \\
\hline Fibre & $6.3 \pm 0.21$ & $7.2 \pm 0.07$ & $6.1 \pm 0.21$ & $3.5 \pm 0.21$ & 27.4 \\
\hline Carbohydrate & $492 \pm 2.83$ & $664 \pm 2.12$ & $467 \pm 2.12$ & $533 \pm 0.07$ & 16.2 \\
\hline Energy $(\mathrm{kJ} / \mathrm{kg})$ & $15895 \pm 82.7$ & $16395 \pm 69.7$ & $15075 \pm 58.7$ & $13733 \pm 113$ & 7.6 \\
\hline $\mathrm{Chi}^{2} \mathrm{C}^{\mathrm{c}}$ & & & & 30.2 & \\
\hline $\mathrm{Chi}^{2} \mathrm{~T}^{\mathrm{d}}$ & & & & 28.9 & \\
\hline Remark & & & & $*$ & \\
\hline
\end{tabular}

${ }^{a}$ Moin-moin = steamed bean pudding; ${ }^{\mathrm{b}} \mathrm{CV} \%=$ coefficient of variation; ${ }^{\mathrm{c}} \mathrm{Chi}{ }^{2} \mathrm{C}=$ chi - square calculated; ${ }^{\mathrm{d}} \mathrm{Chi}-$ square Table; * significant at $\alpha=0.05$; Figures after \pm are standard deviation values.

The statistical observation in the proximate composition showed that most of the values were close on parameter basis with the exception of ash whose CV \% was 90.1 ; the CV \% in moisure was just 5.4. On the whole the $\mathrm{Chi}^{2} \mathrm{C}>\mathrm{Chi}^{2} \mathrm{~T}$ at $\alpha<0.05$, although the significant difference between the samples was positively low.

\section{Mineral composition}

The mineral composition is shown in Table 2. Both $\mathrm{Co}$ and $\mathrm{Cu}$ were not detected. Among the major elements, cake had the highest level of $\mathrm{Na}, \mathrm{K}, \mathrm{Ca}, \mathrm{Mg}$ and $\mathrm{P}$ and also occupied the prime place in the minor element $\mathrm{Zn}(1071 \mathrm{mg} / \mathrm{kg})$. Mn was very low with values ranging from 1.0 $\mathrm{mg} / \mathrm{kg}$ (doughnut) to $2.9 \mathrm{mg} / \mathrm{kg}$ (moin-moin). Generally the CV \% values were close with values ranging from 40.4-67.0. The $\mathrm{Chi}^{2} \mathrm{C}>\mathrm{Chi}^{2} \mathrm{~T}$ at $\alpha<0.05$, although the significant difference was low. 
Table 2. Mineral composition ( $\mathrm{mg} / \mathrm{kg}$ ) of the fast-food samples.

\begin{tabular}{|l|c|c|c|c|c|}
\hline \multirow{2}{*}{ Parameter } & \multicolumn{4}{|c|}{ Fast-food samples } & \multirow{2}{*}{ CV \% } \\
\cline { 2 - 5 } & Meat pie & Doughnut & Moin-moin & Cake & CV \\
\hline Sodium & $328 \pm 1.41$ & $263 \pm 0.71$ & $331 \pm 0.35$ & $611 \pm 0.71$ & 40.4 \\
\hline Potassium & $443 \pm 1.41$ & $361 \pm 1.41$ & $491 \pm 0.71$ & $953 \pm 0.71$ & 47.4 \\
\hline Calcium & $346 \pm 2.12$ & $263 \pm 0.71$ & $460 \pm 0.71$ & $863 \pm 0.71$ & 55 \\
\hline Magnesium & $424 \pm 0.71$ & $358 \pm 0.35$ & $334 \pm 0.71$ & $778 \pm 0.71$ & 43.6 \\
\hline Zinc & $401 \pm 0.35$ & $323 \pm 0.71$ & $525 \pm 0.71$ & $1071 \pm 0.71$ & 58.2 \\
\hline Copper & ND & ND & ND & ND & - \\
\hline Iron & $122 \pm 0.35$ & $119 \pm 0.71$ & $327 \pm 0.71$ & $219 \pm 0.71$ & 50 \\
\hline Cobalt & ND & ND & ND & ND & - \\
\hline Manganese & $1.9 \pm 0.04$ & $1.0 \pm 0.00$ & $2.9 \pm 0.01$ & $2.8 \pm 0.01$ & 40.9 \\
\hline Chromium & ND & ND & ND & ND & - \\
\hline Phosphorus & $347 \pm 0.71$ & $483 \pm 0.71$ & $583 \pm 0.35$ & $1391 \pm 0.35$ & 67 \\
\hline Chi $^{2} \mathrm{C}^{\mathrm{c}}$ & & & & 28.9 & \\
\hline Chi $^{2} \mathrm{~T}^{\mathrm{d}}$ & & & & 28.9 & \\
\hline Remark & & & & $*$ & \\
\hline
\end{tabular}

a-d and $*$ See Table $1 ; \mathrm{e}=$ not determined; ND = not detected.

It is well known that minerals are necessary for life. $\mathrm{Co}, \mathrm{Cu}$ and $\mathrm{Cr}$ were not detected in any of the samples. $\mathrm{Co}$ (II) is a component of vitamin $\mathrm{B}_{12}$ (cyanocobalamin) which is essential for the prevention of anaemia; $\mathrm{Cu}$ and $\mathrm{Fe}$ are present in the enzyme cytochrome oxidase involved in energy metabolism. Since $\mathrm{Co}, \mathrm{Cu}$ and $\mathrm{Cr}$ are needed in the diet, the present samples would need to be supplemented in these minerals when they serve as the only food sources. Iron was high in all the samples but highest in moin-moin $(327 \mathrm{mg} / \mathrm{kg}$ ) which is becoming a weaning food in Nigeria. About $1-10 \%$ of Fe from plant sources is normally absorbed by the body [14] although this value can be improved upon when plants are consumed with meat. For example, the addition of meat to legume or cereal diet can double the amount of $\mathrm{Fe}$ absorbed and so contribute significantly to the prevention of anaemia, which is so widespread in developing countries like Nigeria [14].

Zinc is present in all the samples at high levels. Zinc is present in all tissues of the body and is a component of more than 50 enzymes [14]. The minimum $\mathrm{Zn}$ allowance (about $15-20 \mathrm{mg}$ ) per day would be met by all the samples. The concentration of Mn was low in all the samples. This observation agrees to what obtains in meat [20,21]. Manganese functions as an essential constituent for bone structure, for reproduction and for normal functioning of the nervous system; it is also a part of the enzyme system [21].

Calcium concentration was high in all the samples. Calcium is an important constituent of body fluids. It is a coordinator among inorganic elements particularly $\mathrm{K}, \mathrm{Mg}$ or $\mathrm{Na}$ where calcium is capable of assuming a corrective role when such metals are in excessive amount in the body [21]. Ca, P and vitamin D combine together to avoid rickets in children and osteomalacia (the adult rickets) as well as osteoporosis (bone thinning) among older people [22]. A dietary regime of adequate dietary $\mathrm{Ca}$ over the years should be a deterrent to this condition. All the phosphorus in the samples was high in value. Phosphorus is always found with $\mathrm{Ca}$ in the body, both contributing to the supportive structures of the body. It is present in cells and in the blood as soluble phosphate ion, as well as in lipids, proteins, carbohydrates and energy transfer enzymes [23]. Phosphorus is an essential component in nucleic acids and the nucleoproteins responsible for cell division, reproduction and the transmission of hereditary traits [23].

The samples are good sources of $\mathrm{K}, \mathrm{Mg}$ and $\mathrm{Na}$. Magnesium is an activator of many enzyme systems and maintains the electrical potential in nerves [23]. Potassium is primarily an 
intercellular cation, in large part this cation is bound to protein and with $\mathrm{Na}$ influences osmotic pressure and contributes to normal $\mathrm{pH}$ equilibrium [22].

\section{Mineral ratios}

Table 3 depicts the various mineral ratios that were calculated. The entire CV \% was low (7.229.1). The $\mathrm{Ca} / \mathrm{P}$ was generally greater than 0.5 which is the minimum ratio required for favourable $\mathrm{Ca}$ absorption in the intestine for bone formation [24]. These levels of $\mathrm{Ca} / \mathrm{P}$ ratio would enhance strong bone development since absorption under this condition would be high. $\mathrm{The} \mathrm{Ca} / \mathrm{P}$ ratio is reported to have some effect on $\mathrm{Ca}$ in the blood of many animals [25]. All the $\mathrm{Na} / \mathrm{K}$ values were greater than 0.60 . This is the ratio that favours none enhancement of high blood pressure disease [24] in man. To bring this ratio low, foods rich in potassium should be more consumed. The $\mathrm{Ca} / \mathrm{Mg}$ values ranged between 0.74 and 1.38 whereas the recommended value is 1.0. Both $\mathrm{Ca}$ and $\mathrm{Mg}$ would need adjustment for good health. The milliequivalent ratios of $[\mathrm{K} /(\mathrm{Ca}+\mathrm{Mg})]$ were all less than 2.2. This meant our sample would not promote hypomagnesaemia in man [26].

Table 3. Computed mineral ratios of the fast-food samples.

\begin{tabular}{|l|c|c|c|c|c|c|}
\hline \multirow{2}{*}{ Mineral ratio } & \multicolumn{4}{|c|}{ Fast-food samples } & \multirow{2}{*}{ CV \% } & Standard \\
\cline { 2 - 5 } & Meat pie & Doughnut & Moin-moin & Cake & & \\
\hline $\mathrm{Ca} / \mathrm{P}$ & 0.997 & 0.546 & 0.79 & 0.62 & 27.1 & $\geq 0.5$ \\
\hline $\mathrm{Na} / \mathrm{K}$ & 0.741 & 0.729 & 0.674 & 0.641 & 7.2 & 0.60 \\
\hline $\mathrm{Ca} / \mathrm{Mg}$ & 0.817 & 0.735 & 1.38 & 1.11 & 29.1 & 1.0 \\
\hline$[\mathrm{K} / \mathrm{Ca}+\mathrm{Mg})]^{\mathrm{a}}$ & 1.15 & 1.39 & 1.24 & 1.16 & 8.9 & $<2.2$ \\
\hline
\end{tabular}

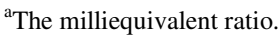

\section{Mineral safety index}

The mineral safety index (MSI) values of the samples are shown in Table 4. The standard MSI for the elements are $\mathrm{Na}(4.8), \mathrm{Mg}$ (15), P (10), $\mathrm{Ca}(10), \mathrm{Fe}$ (6.7) and $\mathrm{Zn}$ (33). For Na, the MSI values ranged from 2.5 (doughnut)-5.9 (cake); only cake had negative difference (-1.1) between the standard and calculated MSI values. This meant that only the cake might be overloading the body with sodium leading to secondary hypertension. For MSI of $\mathrm{Mg}$, meat pie was above the USRDA [17] by 0.9 and cake by 14.2 times. For P, Fe and Zn, the odd samples out, respectively were cake (-1.5); meat pie (-47.5), doughnut (-46.4), moin-moin (-130.3) and cake (-91.0); meat pie (-849.6), doughnut (-676.7), moin-moin (-448.1) and cake (-2323), respectively. The implication of the above is that abnormally high level of $\mathrm{P}$ was present in cake; Fe and $\mathrm{Zn}$ were abnormally present in all the samples. Calcium was normal in all the samples. All the samples could cause the reduction of zinc absorption in the small intestine [27] and iron poisoning particularly in children [28]. All the Zn MSI values were greater than 33. This meant that all the samples have $\mathrm{Zn}$ values far above the recommended adult intake. The minimum toxic dose is $500 \mathrm{mg}$, or 33 times the RDA [17]. High doses of $\mathrm{Zn}$ can be harmful. Zinc supplements can decrease the amount of high density lipoprotein (HDL) circulating in the blood, increasing risk of heart disease [29]. Excess $\mathrm{Zn}$ interacts with other minerals, such as $\mathrm{Cu}$ and $\mathrm{Fe}$, decreasing their absorption. In animals, $\mathrm{Zn}$ supplements decrease the absorption of $\mathrm{Fe}$ so much that anaemia is produced [30]. When patients are given $150 \mathrm{mg}$ of $\mathrm{Zn}$ per day, $\mathrm{Cu}$ deficiency results. Intakes of $\mathrm{Zn}$ only $3.5 \mathrm{mg} /$ day above the RDA decrease $\mathrm{Cu}$ absorption [24]. In animals, $\mathrm{Cu}$ deficiency causes scarring of the heart muscle tissue and low levels of $\mathrm{Ca}$ in the bone [29]. Excess $\mathrm{Zn}$ also decreases the functioning of the immune system. From the foregoing, all the 
samples would lead to excess $\mathrm{Zn}$ consumption with its deleterious effects. It is interesting to note that the current results in the MSI followed the trend observed in different animal samples [31].

Table 4. Mineral safety index of $\mathrm{Na}, \mathrm{Mg}, \mathrm{P}, \mathrm{Ca}, \mathrm{Fe}$ and $\mathrm{Zn}$ for the various fast-food samples.

\begin{tabular}{|c|c|c|c|c|c|c|c|c|c|c|c|c|c|c|c|c|c|c|}
\hline \multicolumn{19}{|c|}{ Mineral Index Safety } \\
\hline \multirow[t]{2}{*}{ Sample } & \multicolumn{3}{|c|}{$\mathrm{Na}$} & \multicolumn{3}{|c|}{$\mathrm{Mg}$} & \multicolumn{3}{|c|}{$\mathrm{P}$} & \multicolumn{3}{|c|}{$\mathrm{Ca}$} & \multicolumn{3}{|c|}{$\mathrm{Fe}$} & \multicolumn{3}{|c|}{$\mathrm{Zn}$} \\
\hline & $\mathrm{TV}^{\mathrm{a}}$ & $\begin{array}{l}\text { CV } \\
\text { b }\end{array}$ & $\mathrm{D}^{\mathrm{c}}$ & TV & $\mathrm{CV}$ & D & TV & $\mathrm{CV}$ & D & TV & $\mathrm{CV}$ & D & TV & $\mathrm{CV}$ & D & TV & $\mathrm{CV}$ & D \\
\hline $\begin{array}{l}\text { Meat } \\
\text { pie }\end{array}$ & 4.8 & 3.2 & 1.6 & 15 & 15.9 & -0.9 & 10 & 2.9 & 7.1 & 10 & 2.9 & 7.1 & 6.7 & 54.6 & -47.5 & 33 & 882.6 & 849.6 \\
\hline $\begin{array}{l}\text { Dough } \\
\text { nut }\end{array}$ & 4.8 & 2.5 & 2.3 & 15 & 13.4 & 1.6 & 10 & 4.0 & 6.0 & 10 & 2.2 & 7.8 & 6.7 & 53.1 & -46.4 & 33 & 709.7 & 676.7 \\
\hline Moin-moin & 4.8 & 3.2 & 1.6 & 15 & 12.5 & 2.5 & 10 & 4.8 & 5.2 & 10 & 3.8 & 6.2 & 6.7 & \begin{tabular}{|l|}
146. \\
0
\end{tabular} & \begin{tabular}{|l} 
\\
130.3 \\
\end{tabular} & 33 & 481.1 & $\begin{array}{l}- \\
448.1 \\
\end{array}$ \\
\hline Cake & 4.8 & 5.9 & -1.1 & 15 & 29.2 & $\begin{array}{l}- \\
14.2 \\
\end{array}$ & 10 & $\begin{array}{l}11 . \\
5\end{array}$ & -1.5 & 10 & 7.2 & 2.8 & 6.7 & 97.7 & -91.0 & 33 & 2356 & -2323 \\
\hline Mean & $-d$ & 3.7 & 1.1 & - & 17.8 & -2.8 & - & 5.8 & 4.2 & - & 4.0 & 6.0 & - & 87.9 & -81.1 & - & 1107.4 & -1074 \\
\hline SD & - & 1.5 & 1.5 & - & 7.8 & 7.8 & - & 3.9 & 3.9 & - & 2.2 & 2.2 & - & 43.9 & 44 & - & 848.5 & 849 \\
\hline $\mathrm{CV} \%$ & - & \begin{tabular}{|l|}
40. \\
6 \\
\end{tabular} & \begin{tabular}{|l|}
136 \\
.4 \\
\end{tabular} & - & 43.6 & -279 & - & $\begin{array}{l}66 . \\
9 \\
\end{array}$ & \begin{tabular}{|l}
92. \\
4 \\
\end{tabular} & - & \begin{tabular}{|l|}
55. \\
0 \\
\end{tabular} & \begin{tabular}{|l|}
37. \\
1 \\
\end{tabular} & - & 50.0 & -54.3 & - & 76.6 & -79.0 \\
\hline
\end{tabular}

${ }^{\mathrm{a}} \mathrm{TV}=$ table value $;{ }^{\mathrm{d}}-\mathbf{=}$ not determined $;{ }^{\mathrm{b}} \mathrm{CV}=$ calculated value $;{ }^{\mathrm{c}} \mathrm{D}=$ difference.

\section{Mineral bioavailability}

The phytate (Phy), Ca:Phy, Phy:Zn and [Ca][Phy]/[Zn] of the samples are shown in Table 5. Phytate was highest $(2554 \mathrm{mg} / \mathrm{kg})$ in moin-moin among the samples. The Ca:Phy was the most varied with $\mathrm{CV} \%$ of 92.2 . The $\mathrm{Chi}^{2} \mathrm{C}<\mathrm{Chi}^{2} \mathrm{~T}$ at $\alpha<0.05$ and the differences among the samples were not significant. Oberleas and Harland [32] showed that foods with a molar ratio of Phy: $\mathrm{Zn}$ less than 10 showed adequate availability of $\mathrm{Zn}$ and problems were encountered when the values were greater than 15. In Table 5, all the Phy: $\mathrm{Zn}$ values were below 1.0 showing that $\mathrm{Zn}$ would be available under this model. Wise [33] suggested that the solubility of the phytate and the proportion of $\mathrm{Zn}$ bound in a mineral complex in the intestines depend on the levels of calcium. In this model, phytate precipitation is not complete until dietary Ca:Phy molar ratio attains a value of approximately 6:1. At Ca:Phy molar ratios lower than 6:1, phytate precipitation is incomplete, so that some of the dietary zinc remains in solution. The proportion remaining in solution increases with decreasing Ca:Phy molar ratios [33]. In our results only cake result (11.5) was above the critical molar ratio of $6: 1$. Hence, the calcium content of the other fast-foods might be sufficient to promote phytate-induced decreases in zinc bioavailability [34]. Ferguson et al. [35] showed that the molar ratio varies with different foods and recommended that this value be used in conjunction with other data to explain the availability of $\mathrm{Zn}$ using the $\mathrm{Ca}$ :Phy ratio. Our results for $[\mathrm{Ca}][\mathrm{Phy}] /[\mathrm{Zn}]$, that is $(\mathrm{Ca} \mathrm{x}$ Phy:Zn) are also in Table 5. Ellis et al. [36] and Davies and Warrington [37] indicated that the ratio of Ca x Phy:Zn is a better predictor of $\mathrm{Zn}$ availability and said that, if the value were greater than $0.50 \mathrm{~mol} / \mathrm{kg}$ there would be interferences with the availability of $\mathrm{Zn}$. In our results, Ca x Phy: $\mathrm{Zn}$ values were all lower than $0.50 \mathrm{~mol} / \mathrm{kg}$, that is to say using this indicator, $\mathrm{Zn}$ would be available in all the samples. The results here are in total agreement with the results in 35 food samples of major consumption in Nigeria [38]. 
Table 5. Phytate (Phy), Ca:Phy, Phy:Zn and [Ca][Phy]/[Zn] of the fast-food samples.

\begin{tabular}{|l|c|c|c|c|c|}
\hline \multirow{2}{*}{ Parameter } & \multicolumn{4}{|c|}{ Fast-food samples } & \multirow{2}{*}{ CV \% } \\
\cline { 2 - 5 } & Meat pie & Doughnut & Moin-moin & Cake & \\
\hline Phytate $(\mathrm{mg} / \mathrm{kg})$ & 2183 & 1936 & 2554 & 1236 & 28.1 \\
\hline $\mathrm{Ca} / \mathrm{Phy}$ & 2.61 & 2.24 & 2.97 & 11.49 & 92.2 \\
\hline Phy/Zn & 0.54 & 0.59 & 0.48 & 0.11 & 50.7 \\
\hline$[\mathrm{Ca}][\mathrm{Phy}] /[\mathrm{Zn}]$ & 0.047 & 0.039 & 0.056 & 0.046 & 14.8 \\
\hline $\mathrm{Chi}^{2} \mathrm{C}^{\mathrm{c}}$ & & & & 10.8 & \\
\hline $\mathrm{Chi}^{2} \mathrm{~T}^{\mathrm{d}}$ & & & & 12.6 & \\
\hline Remark & & & & NS & \\
\hline
\end{tabular}

$\mathrm{a}-\mathrm{d}=$ see Table $1 ; \mathrm{NS}=$ not significant at $\alpha=0.05 ; \mathrm{Ca} / \mathrm{Phy}=\mathrm{mg}$ of Ca/AW of Ca: mg of PHY/AW of Phy, $\mathrm{Phy} / \mathrm{Zn}=\mathrm{mg}$ of Phy/AW of Phy: mg of Zn/AW of Zn; [Ca][Phy]/[Zn] = $(\mathrm{mol} / \mathrm{kgCa})(\mathrm{mol} / \mathrm{kgZn})$.

\section{Amino acids composition}

The amino acids compositions of the fast-foods are shown in Table 6 . The least varied amino acid in the samples was alanine with CV \% of 1.3 while cystine was the most varied with CV \% of 37.9. The most concentrated amino acid in all the samples was glutamic acid which ranged from $80.5 \mathrm{mg} / \mathrm{g}$ (doughnut) $-115 \mathrm{mg} / \mathrm{g}$ crude protein (moin-moin). This is also the most concentrated amino acid in coconut endosperm [39]. Statistical differences were significant among the samples (Table 6).

Table 6. Amino acid composition (mg/g crude protein) of the fast-food samples.

\begin{tabular}{|c|c|c|c|c|c|}
\hline \multirow[t]{2}{*}{ Parameter } & \multicolumn{4}{|c|}{ Fast-food samples } & \multirow[t]{2}{*}{$\mathrm{CV} \%$} \\
\hline & Meat pie & Doughnut & Moin-moin & Cake & \\
\hline Lysine $^{a}$ & $24.1 \pm 0.07$ & $35.8 \pm 0.01$ & $22.6 \pm 0.01$ & $29.7 \pm 0.01$ & 21.4 \\
\hline Histidine $^{\mathrm{a}}$ & $16.2 \pm 0.07$ & $24.1 \pm 0.01$ & $11.7 \pm 0.01$ & $22.4 \pm 0.07$ & 30.7 \\
\hline Arginine $^{\mathrm{a}}$ & $43.2 \pm 0.07$ & $39.7 \pm 0.07$ & $48.2 \pm 0.01$ & $41.5 \pm 0.14$ & 8.5 \\
\hline Aspartic acid & $42.2 \pm 0.04$ & $43.5 \pm 0.06$ & $56.0 \pm 0.14$ & $66.9 \pm 0.14$ & 22.3 \\
\hline Threonine $^{\mathrm{a}}$ & $17.4 \pm 0.07$ & $20.4 \pm 0.25$ & $17.1 \pm 0.01$ & $23.0 \pm 0.07$ & 14.3 \\
\hline Serine & $21.5 \pm 0.04$ & $30.0 \pm 0.01$ & $20.3 \pm 0.07$ & $38.8 \pm 0.01$ & 31.0 \\
\hline Glutamic acid & $81.2 \pm 0.07$ & $80.5 \pm 0.001$ & $115 \pm 1.41$ & $82.8 \pm 0.04$ & 18.8 \\
\hline Proline & $14.1 \pm 0.04$ & $21.3 \pm 0.07$ & $16.9 \pm 0.01$ & $21.9 \pm 0.56$ & 20.0 \\
\hline Glycine & $29.0 \pm 0.04$ & $20.2 \pm 0.01$ & $25.2 \pm 0.04$ & $31.8 \pm 0.04$ & 18.9 \\
\hline Alanine & $29.8 \pm 0.04$ & $30.6 \pm 0.07$ & $30.1 \pm 0.04$ & $30.6 \pm 0.04$ & 1.3 \\
\hline Cystine & $10.6 \pm 0.07$ & $13.7 \pm 0.01$ & $20.0 \pm 0.04$ & $26.5 \pm 0.01$ & 37.9 \\
\hline Valine $^{\mathrm{a}}$ & $26.0 \pm 0.04$ & $33.2 \pm 0.14$ & $35.6 \pm 0.01$ & $26.4 \pm 0.04$ & 15.9 \\
\hline Methionine $^{\mathrm{a}}$ & $7.5 \pm 0.004$ & $12.8 \pm 0.01$ & $7.7 \pm 0.001$ & $11.0 \pm 0.04$ & 26.4 \\
\hline Isoleucine $^{\mathrm{a}}$ & $25.7 \pm 0.04$ & $26.4 \pm 0.01$ & $26.3 \pm 0.00$ & $31.6 \pm 0.01$ & 10.0 \\
\hline Leucine $^{\mathrm{a}}$ & $32.6 \pm 0.001$ & $44.3 \pm 0.07$ & $43.0 \pm 0.07$ & $41.2 \pm 0.04$ & 13.1 \\
\hline Tyrosine & $14.4 \pm 0.04$ & $26.3 \pm 0.07$ & $23.5 \pm 0.04$ & $19.4 \pm 0.01$ & 24.8 \\
\hline Phenylalanin $^{\mathrm{a}}$ & $26.2 \pm 0.001$ & $25.9 \pm 0.07$ & $42.6 \pm 0.01$ & $30.5 \pm 0.06$ & 25.0 \\
\hline $\mathrm{Chi}^{2} \mathrm{C}$ & & & & 68.4 & \\
\hline $\mathrm{Chi}^{2} \mathrm{~T}$ & & & & 67.5 & \\
\hline Remark & & & & $*$ & \\
\hline
\end{tabular}

${ }^{a}$ Essential amino acid; $*$ significant at $\alpha=0.05$.

Table 7 depicts the essential amino acids (EAA) in the samples. With the exception of His in moin-moin $(11.7 \mathrm{mg} / \mathrm{g})$ all the EAA were greater than the suggested patterns of amino acid requirements in adults. Tryptophan was not determined. The suggested patterns of total EAA 
requirement from literature were (mg/g): including His: 460 (infant), 339 (pre-school child), 241 (school child) and 127 (adult) [40]; whereas our own values with His were 201 (meat pie), 263 (doughnut), 250 (moin-moin) and 261 (cake). The suggested patterns without His were: 434 (infant), 320 (pre-school), 222 (school child) and 111 (adult) [40]; whereas our own values without His were: 185 (meat pie), 239 (doughnut), 238 (moin-moin) and 238 (cake), these values were either greater or close to the required daily intake of amino acids particularly for adults and school children.

Table 7. Essential amino acid composition (mg/g crude protein) of the fast-food samples.

\begin{tabular}{|l|c|c|c|c|c|}
\hline \multirow{2}{*}{ Parameter } & \multicolumn{4}{|c|}{ Fast-food samples } & \multirow{2}{*}{ CV \% } \\
\cline { 2 - 5 } & Meat pie & Doughnut & Moin-moin & Cake & \\
\hline Lysine & 24.1 & 35.8 & 22.6 & 29.7 & 21.4 \\
\hline Histidine & 16.2 & 24.1 & 11.7 & 22.4 & 30.7 \\
\hline Arginine & 43.2 & 39.7 & 8.2 & 41.5 & 8.5 \\
\hline Methionine & 7.5 & 12.8 & 7.7 & 11.0 & 26.4 \\
\hline Threonine & 17.4 & 20.4 & 17.1 & 23.0 & 14.3 \\
\hline Isoleucine & 25.7 & 26.7 & 26.3 & 31.6 & 10.0 \\
\hline Valine & 26.0 & 33.2 & 35.6 & 26.5 & 15.9 \\
\hline Leucine & 32.6 & 44.3 & 43.0 & 41.2 & 13.1 \\
\hline Phenylalanine & 26.2 & 25.9 & 42.6 & 30.5 & 25.0 \\
\hline $\mathrm{X}^{2} \mathrm{C}$ & & & & 38.5 & \\
\hline $\mathrm{X}^{2} \mathrm{~T}$ & & & & 36.4 & \\
\hline Remark & & & & $*$ & \\
\hline
\end{tabular}

$*$ significant at $\alpha=0.05$.

Histidine is a semi-essential amino acid particularly useful for children growth. It is a precursor of histamine present in small quantities in cells. When allergens enter the tissues it is liberated in larger quantities and is responsible for nettle rash [41]. The values of isoleucine ranged from 25.7-31.6 mg/g crude protein in the samples. It is an EAA for both old and young. The isoleucine levels were all high. Male Syrup Urine Disease is an inborn error of metabolism in which brain damage and early death can be avoided by a diet low in isoleucine and two other EAA, leucine and valine [39]. While our Ile, Leu and Val were good for pre-school child and school child, they were far greater than the requirements for adults. Methionine is an EAA and ranged from 7.5-12.8 mg/g in the samples. With cystine, it ranges from 18.1-36.4 mg/g. These values would satisfy the three upper age limits. Methionine is needed for the synthesis of choline. Choline forms lecithin and other phospholipids in the body. When the diet is low in protein, for instance in alcoholism and kwashiorkor, insufficient choline may be formed; this may cause accumulation of fat in the liver [41]. Consumers of our samples would consume more than enough methionine. Phenylalanine ranged from $25.9-42.6 \mathrm{mg} / \mathrm{g}$ in the samples. In addition to tyrosine, it ranged from $40.6-66.1 \mathrm{mg} / \mathrm{g}$. These are good for pre-school child, school child and adults [40]. Phenylalanine is the precursor of some hormones and the pigment melanin in hair, eyes and tanned skin. The Tyr values ranged between $14.4-26.3 \mathrm{mg} / \mathrm{g}$ in the samples (Table 6). Tyrosine is the precursor of some hormones (like the thyroid hormones) and the brown pigment melanin formed in hair, eyes and tanned skin. It reduces the requirement of Phe. Permanent deficiency of the enzyme-hypertyrosinaemia, a rare inborn error of metabolism can cause liver and kidney failure unless treated with a synthetic diet low in Phe + Tyr [41]. Valine was high in our samples (26.0-35.6 mg/g). Valine is restricted in the treatment of Maple Syrup Urine Disease. The Cys/Cys + Met $(\%)$ values were high in the samples: meat pie $(58.6 \%)$, doughnut $(51.7 \%)$, moin-moin $(72.2 \%)$ and cake $(69.8 \%)$. The percent Cys in TSAA in ripe coconut endosperm was 62.9 [39]. Information on the agronomic advantages of increasing 
the concentration of sulphur-containing amino acids in staple foods shows that Cys has positive effects on mineral absorption, particularly $\mathrm{Zn}[42,43]$.

Table 8 contains the EAA scores of the fast-foods. Both Lys and Thr shared the lowest level of 0.44 in meat pie. Thr was the lowest $(0.51)$ in doughnut, Thr was the lowest $(0.43)$ in moinmoin and Lys was the lowest (0.54) in cake. The first limiting amino acid is Lys, second is Met + Cys and third is Thr. Hence to correct for limiting amino acid in meat pie, 100/44 (for Lys or Thr) or 2.27 times as much of meat pie protein would have to be eaten when it is the sole protein source in the diet; in doughnut it is $100 / 51$ or 1.96 times proteins; in moin-moin it is $100 / 43$ or 2.33 times protein; in cake it is $100 / 54$ or 1.85 times protein to correct for limiting Lys. The CV \% was generally low in the EAA scores with value range of $10.0-27.3$. The $\mathrm{Chi}^{2} \mathrm{C}$ $>\mathrm{Chi}^{2} \mathrm{~T}, \alpha<0.05$ although the value of significant difference was not high.

Table 8. Amino acid scores of the fast-food samples.

\begin{tabular}{|l|c|c|c|c|c|c|}
\hline \multirow{2}{*}{ Parameter } & \multirow{2}{*}{ Scoring pattern $^{\mathrm{a}}$} & \multicolumn{4}{|c|}{ Fast-food samples } & \multirow{2}{*}{ CV \% } \\
\cline { 3 - 6 } & & Meat pie & Doughnut & Moin-moin & Cake & \\
\hline Isoleucine & 40 & 0.64 & 0.66 & 0.66 & 0.79 & 10.0 \\
\hline Leucine & 70 & 0.47 & 0.63 & 0.61 & 0.59 & 12.4 \\
\hline Lysine & 55 & 0.44 & 0.65 & 0.41 & 0.54 & 21.3 \\
\hline Met + Cys & 35 & 0.52 & 0.76 & 0.79 & 1.04 & 27.3 \\
\hline Phe +Tyr & 60 & 0.68 & 0.87 & 1.10 & 0.83 & 20.0 \\
\hline Threonine & 40 & 0.44 & 0.51 & 0.43 & 0.56 & 12.5 \\
\hline Tryptophan & 10 & - & - & - & - & - \\
\hline Valine & 50 & 0.52 & 0.66 & 0.71 & 0.53 & 15.5 \\
\hline$X^{2} \mathrm{C}$ & & & & & 31.4 & \\
\hline $\mathrm{X}^{2} \mathrm{~T}$ & & & & & 28.9 & \\
\hline Remark & & & & & $*$ & \\
\hline
\end{tabular}

${ }^{\mathrm{a} P r o v i s i o n a l ~ a m i n o ~ a c i d ~ s c o r i n g ~ p a t t e r n ~(m g / g ~ o f ~ p r o t e i n) ; ~ * ~=~ s i g n i f i c a n t ~ a t ~} \alpha=0.05$.

\section{CONCLUSIONS}

In summary this study indicates that the fast-foods are not just unhealthy foods as they are good sources of protein, carbohydrate, mineral and amino acids. However, the level of iron and zinc may be antagonistic to the absorption of other minerals, sodium may enhance secondary hypertension and lysine rich foods may be eaten to supplement in meat pie and cake consumption.

\section{REFERENCES}

1. Crocetti, A.F.; Guthrie, H.A. Clin. Nutr. 1986, 5, 34.

2. Ries, C.P.; Kline, K.; Weaver, S.O. J. Am. Diet. Assoc. 1987, 87, 463.

3. Owhe-Ureghe, U.B.; Ekundayo, A.O.; Agbonlahor, D.E.; Oboh, P.A.; Orhue, P. Nig. Food J. 1993, 11, 45.

4. Bertram, P. Fast Food Operations, Barrie and Jenkins Limited: London; 1975; p 100.

5. WHO/FNU/FOS.; Food Safety Issues - Essential Safety Requirements for Street - vended Foods (revised edition). WHO/FNU/FOS; 1996; 96.7; $\mathrm{p} 2$.

6. AOAC Official Methods of Analysis. 15th ed., Association of Official Analytical Chemists: Washington, DC; 1990; Section 12.1.7; 968.08; 4.1.28.

7. Pearson, D. Chemical Analysis of Foods, 7th ed., J. and A. Churchill: London; 1976; 7. 
8. Varian Techtron Basic Atomic Absorption Spectroscopy- A Modern Introduction, Dominica Press: Victoria; 1975; p 104.

9. Harland, B.F.; Oberleas, D. J. Assoc. Off. Anal. Chem. 1986, 69, 667.

10. FAO/WHO Protein Quality Evaluation, Report of Joint FAO/WHO Expert Consultation, FAO Food and Nutrition Paper No. 51, FAO/WHO: Rome; 1991; 10.

11. FAO/WHO Protein Quality Evaluation, Report of Joint FAO/WHO Expert Consultation Held in Bethseda MD, 4-8 December, 1989, FAO: Rome; 1990; p 1.

12. Orr, L.; Watt, B.K. Amino Acid Content of Foods, Home Economics Research Report 4, USDA, USA: Washington DC; 1975; p 30.

13. FAO Amino Acid Content of food and Biological Data on Proteins, FAO Nutritional Studies No. 24, FAO: Rome; 1970; p 21.

14. Bender, A. Meat and Meat Products in Human Nutrition in Developing Countries, FAO Nutrition Paper 53, FAO: Rome; 1992; p 1.

15. Wyatt, C.J.; Triana-Tejas A. J. Agric. Food Chem. 1994, 42, 2204.

16. Steel, R.G.D.; Torrie, J.H. Principles and Procedures of Statistics, McGraw-Hill: London; 1960; $\mathrm{p} 1$.

17. Hathcock, J.N. Pharmacy Times 1985, May, 104.

18. Selvendran, R.R.; Ring, S.G.; Du Pont, M.S. Chemistry and Industry, 1979, 7, 225.

19. Paul, A.A.; Southgate, D.A.T. McCance and Widdowson's The Composition of Foods, 4th ed., Her Majesty's Stationery Office: London; 1978; p 227.

20. Adeyeye, E.I. Int. J. Fd. Sci. Nutr. 1996, 47, 111.

21. Flecks, H. Introduction to Nutrition, 3rd ed., Macmillan: New York; 1976; p 1.

22. Moldawer, M.; Zimmerman, S.J.; Collins, L.C. J. Am. Med. Assoc. 1965, 194, 859.

23. Adeyeye, E.I.; Agesin, O.O. Bangladesh J. Sci. Ind. Res. 2007, 42, 163.

24. Nieman, D.C.; Butterworth, D.E.; Nieman, C.N.; Nutrition, Wm. C. Brown Publishers: Dubuque; 1992; p 20.

25. Adeyeye, E.I.; Faleye, F.J. J. Appl. Env. Sci. 2007, 3, 150.

26. National Research Council Food and Nutrition Board Recommended Dietary Allowances, 10th ed.; National Academy Press: Washington DC; 1989; $\mathrm{p} 82$.

27. O'Dell, B.L. Nutr. Rev. 1984, 42, 301.

28. Herbert, V. Am. J. Nutr. 1987, 45, 679.

29. Anonymous Adverse effects of zinc megadoses, Nutrition and the MD, 1986; available at: http:/www.en.wikipedia.org/wiki/Orthomolecular_medicine

30. Greger, J.L. J. Am. Diet. Assoc. 1987, 87, 1369.

31. Adeyeye, E.I.; Faleye, F.J. Pak. J. Sci. Ind. Res. 2004, 47, 471.

32. Oberleas, D.; Harland, B.F. J. Am. Diet. Assoc. 1981, 79, 433.

33. Wise, A. Nutr. Abst. Rev/Rev. Clin. Nutr. 1986, 53, 791.

34. Ferguson, E.I.; Gibson, R.S.; Thompson, L.V.; Ounpuu, S.; Berry, M. J. Food Comp. Anal. 1988, $1,316$.

35. Ferguson, E.I.; Gibson, R.S.; Thompson, L.V.; Ounpuu, S.; Berry, M. Am. J. Clin. Nutr. 1989, 50, 1450.

36. Ellis, R.; Kelsay, J.L.; Reynolds, R.D.; Morris, E.R.; Moser, P.B.; Frazier, C.W. J. Am. Diet. Assoc. 1987, 87, 1043.

37. Davies, N.T.; Warrington, S. Hum. Nutr. Appl. Nutr. 1986, 40A, 49.

38. Adeyeye, E.I.; Arogundade, L.A.; Akintayo, E.T.; Aisida, O.A.; Alao, P.A. Food Chem. 2000, 7, 435.

39. Adeyeye, E.I. Orien. J. Chem. 2004, 20, 471. 
40. FAO/WHO/UNU.; Energy and Protein Requirements. Report of a Joint FAO/WHO/UNU Expert Consultation on Energy and Protein Requirements, World Health Organization Technical Report Series 724, WHO: Geneva; 1985; pp. 113-129.

41. Bingham, S. Dictionary of Nutrition, Barrie and Jenkins Limited: London; 1977; p 76. 42. Mendosa, C. Inter. J. Food Sci. Tec. 2002, 37, 759.

43. Sandstorm, B.; Almgren, A.; Kivisto, B.; Cederblad, A. J. Nutr. 1989, 119, 48. 